Martine DELVAUX

Literary Studies, University of Québec

Montréal, Canada

delvmart@videotron.ca

\title{
TAKE LEMONS AND MAKE LEMONADE: SERIAL GIRLS AND THE QUESTION OF RACE
}

Recommended Citation: Delvaux, Martine. "Take Lemons and Make Lemonade: Serial Girls and the Question of Race." Metacritic Journal for Comparative Studies and Theory 4.1 (2018): https://doi.org/10.24193/mjcst.2018.5.03

\begin{abstract}
This paper addresses the question of race in relation to the image of serial girls. I reflect on how seriality affects women of colour and how it operates by imposing an ideal white female body and an ideal image of femininity. I am also interested in the way seriality is used by artists of colour, as a means for resistance against white cultural supremacy and (white) misogyny. Beyoncé is one example of how seriality can be reproduced in order to resist. Some relevant proof I analyse in this paper are the 2016 Superbowl performance and the film-album Lemonade. In this context, the image of serial girls appears both as a symptom of racism and as a possibility of anti-racist engagement.
\end{abstract}

Key words: Seriality, girls, women, race, Beyoncé, white supremacy, misogyny

In "On being white and other lies," James Baldwin approaches the notion of becoming white. He considers that we are not born white, instead we become white:

America became white because of the necessity of denying the black presence, and justifying the Black subjugation. No community can be based on such a principle - or, in other words, no community can be established on so genocidal a lie. White men - from Norway, for example, where they were Norwegians - became white: by slaughtering the 
cattle, poisoning the wells, torching the houses, massacring Native Americans, raping Black women (Baldwin in Roediger 178).

Being white is a moral choice according to Baldwin. It is something that you think you are. Therefore, there are no white people, just as Black people were only defined as such by the slave trade. However, it is hard to give up the "comfort of being «naturally better than,» of not having to struggle or demand civil treatment," as Toni Morrison pointed out after Donald Trump's election (Morrison 2016). It is hard because it is frightening to be stripped of the illusion of superiority which lies at the core of white identity. Therefore, what Morrison reads on the faces of the white electors is not so much that they are angry, but that they are terrified to lose their whiteness.

My analysis questions two main aspects of Baldwin's moral choice. The first one revolves around how one becomes white and how women become white regardless of their will. The reason behind this is the prevalence of an image that configures the female bodies placed together: the image of serial girls. The second aspect is how one might work at undoing this transformation, how one might try to un-become white in order to undo what bell hooks calls an "imperialist white supremacist capitalist patriarchy" (in Yancy and hooks, Dear White America).

I will start my analysis with a story which is not very becoming to me but forced me to face my own unbecoming.

In August 2016, a Montreal bookstore organized a round table in honour of the Journée du livre québécois (Québécois Book Day) with several white female writers from Québec. Each one of us was invited separately and only when the program was finalized did we realize that each one of us was white.

We spoke up against this and offered to give up our spot in order to include a nonwhite female writer in our place. The bookstore explained that they had unsuccessfully tried to find non-white speakers. How many non-white female writers had been approached? We did not know. Why did none of us ask if there would be non-white female writers on the panel before even agreeing to participate in the event? Because it did not cross our minds. 
What if the word white had been in the title of the panel? What if I had been invited to a round table of "white female writers of Québec"? Would I have agreed to take part in it? No, I would not have accepted to be identified as a member of this select group of white women. What would that have meant? Two reasons would have justified my rejection: 1) I would have refused to be part of an event identified as being organised by and for white people, implicitly refusing to be a party to white supremacy. 2) At the same time, I would have refused to recognize the colour of my own skin and the fact that, whether I like it or not, I am a part of this system. If the word white had been in the title of the panel, I would have been so ashamed that my reaction would have been to erase whiteness itself, erasing my own whiteness as well.

As the panel took place after all, I asked the moderator to focus on lack of diversity, keeping in mind the stance taken by the literature of Québec. But the bookstore did nothing more than to formally apologise at the beginning of the event. The panel continued as planned initially. High jacking the roundtable failed, but the event itself contributed to my discovery that I am white ${ }^{1}$. Perhaps I was not guilty, but I was definitely responsible ${ }^{2}$. And if History - my history - made me white, nothing ever forced me to remain this way. I was not compelled to stay within this series, to be part of the white serial girls.

I consider essential to my approach George Yancy's letter "Dear White America" published in The New York Times as an introduction to a series of interviews he conducted with various philosophers on the topic of race:

As a sexist, I have failed women, I have failed to speak out when I should have. I have failed to engage critically and extensively their pain and suffering in my writing. I have failed to transcend the rigidity of gender roles in my own life.... I have been complicit with, and have allowed myself to be seduced by, a country that makes billions of dollars from sexually objectifying women, from pornography, commercials, video games, to Hollywood movies. I am not innocent. (...) If you are white, and you are reading this letter, I ask that you don't run to seek shelter from your own racism. Don’t hide from

${ }^{1}$ A complete version of this event was published in "Blanches" (co-authored with Carole David), À bâbord, Vol 67, Dec 2016 - Jan 2017, https://www.ababord.org/Blanches.

${ }^{2}$ As Houria Bouteldja writes in Les Blancs, les Juifs et nous: "Vous "découvrez» que vous êtes blancs lorsque nous vous nommons "Blancs». En fait vous ne découvrez rien. Vous répugnez juste à être nommés, situés et qu'ainsi soit dévoilée votre culpabilité et rendue vulnérable votre immunité." (37). 
your responsibility. Rather, begin, right now, to practice being vulnerable. (...) I ask that you try to be "un-sutured" (Yancy, "Dear White America”).

While serial girls evoke the becoming of an image when it is overdone, my intention is to analyse its promise of un-suturing and un-becoming.

The desire for sameness behind the image of serial girls is white and thin 3 . Its standard characteristics are sizable breasts, a small waist, a flat stomach, shapely long legs, and long straight blond hair. This Western standard is given as a universal form, to which all women around the globe end up being compared to, regardless of their identity, colour of skin or gender identity. This hegemonic image aims to be universal, cancelling out the place of real women - especially women of colour and non-cis women -, and erasing the actual human beings, their materiality, their specificity, and their differences either effectively or symbolically. A further analysis of this image can be offered by finding its traces in the writings of James Baldwin via Raoul Peck's film I Am Not Your Negro. To trace this analysis, I follow the steps of Baldwin and Peck to see how they refer to and represent white women as the embodiment of white supremacy through the image of the serial girls. I focus on the political dimension of the image of serial girls in order to show how it carries a history of racism as a well as a potential for resistance.

At the beginning of I Am Not a Negro, we hear an excerpt where Baldwin insists on mentioning that he does not at all miss an America that he could very well live without. At the same time, he makes a list of things he does miss: his brothers and sisters, his mother, Sunday mornings in Harlem, its music and style. For instance, Baldwin depicts the style as a characteristic that no one else has on this planet, except for Harlem. Raoul Peck accompanies this description of Harlem and its style with close-ups of the faces of the Black women. This sequence is followed by two shots in which we see Black boys playing and a Black man, who has his back to us. Then we see, jump-cut, an

3 I have studied the image of serial girls at length in Serial Girls. From Barbie to the Pussy Riot, Toronto: Between the Lines, 2017. 
excerpt of Dance, Fools, Dance, a Beaumont film of 1931 with Joan Crawford. We hear Baldwin's words:

I am fascinated by the movement on and off the screen. I am about seven. I am with my mother, or my aunt. The movie is Dance, Fools, Dance. I was aware that Joan Crawford was a white lady. Yet, I remember being sent to the store sometime later, and a colored woman, who, to me, looked exactly like Joan Crawford, was buying something. She was incredibly beautiful... She looked down at me with so beautiful a smile that I was not even embarrassed. Which was rare for me (Baldwin in Peck 15).

In a 1961 interview, Baldwin refers to Joan Crawford once again. In response to Studs Terkel's question: "Did you feel a sense of shame about a heritage that is really so rich, when you accepted the white man's stereotype of yourself?” Baldwin answers:

You go to white movies and, like everybody else, you fall in love with Joan Crawford, and you root for the Good Guys who are killing off the Indians. It comes as a great psychological collision when you realize all of these things are really metaphors for your oppression (...) (Baldwin 6).

In Peck's movie, Joan Crawford's smile morphs into the hand of Bill Miller, his primary school teacher, who is "a beautiful woman, very important to me." This white woman with a masculine name gives books to the young James Baldwin and talks to him about them and the world. And it may be because of her, because of how she showed up in his terrified life at such a young age that he was never able to hate white people. He took her for who she was, or who she was for him at least: a white woman who was treated, because of her political position, as black. Baldwin never hated white people but he often wished he could kill one or two of them. This is what we hear him say as Peck moves his camera from World War II imagery to a shot of the blond Fay Wray tied to a post by natives who want to offer her in sacrifice to King Kong. Fay Wray functions as a symbol of the whiteness menaced by a gigantic black ape. But in the end, as the last words of the original movie say, "beauty killed the beast".

But is beauty meant to kill the beast? Is this what serial girls - namely white serial girls - are for? 
Films and images are at the centre of the narrative which Peck weaves of Baldwin's life. Heroes were white. There were no men on screens who resembled Peck's father. He remembers the janitor in the movie They Won't Forget, a man who was questioned because a young white girl was raped and killed on the premises where he works. Terrified, he was crying in front of the policemen. Haunted by his face, Baldwin writes: "the film's icy brutality both scared me and strengthened me" (Baldwin in Peck 21). There is a connection between King Kong, the janitor, Medgar Evers, Malcolm X, Martin Luther King and James Baldwin, which is a connection Raoul Peck made through his distinct editing of the movie. We hear Baldwin speak to Kenneth Clark about white people: "These people have deluded themselves for so long that they don't really think I'm human. And I base this on their conduct, not on what they say. And this means that they have become in themselves moral monsters" (Baldwin in Peck 39). This expression, moral monsters, gives way to a sequence that shows a beauty pageant and young white women in white bathing suits, posing at the centre of the image. Then, under a bright blue sky, we see them running, free and easy, with a big smile on their faces, in white crisp cotton shirts, with their gaze looking down into the camera. The words of Baldwin accompany this shot:

History is not the past. It is the present. We carry our history with us. We are our history. If we pretend otherwise, we literally are criminals. I attest to this: the world is not white; it never was white, cannot be white. White is a metaphor for power, and that is simply a way of describing Chase Manhattan Bank (Baldwin in Peck 107).

I follow the traces of white women in Raoul Peck's movie, and the way in which they appear on screen and in Baldwin's texts. I follow them to the end, when, after the image of a blonde and perky Doris Day, Peck cuts to a photograph of Laura Nelson, a Black woman hung to a tree, lynched in 1911, in Oklahoma. "You cannot lynch me," writes Baldwin,

and keep me in ghettos without becoming something monstrous yourselves. And furthermore, you give me a terrifying advantage. You never had to look at me. I had to 
look at you. I know more about you than you know about me. Not everything that is faced can be changed; but nothing can be changed until it is faced (Baldwin in Peck 103).

Peck ends his film with a series of close-ups of faces. The last one is of a young black woman. But neither her nor Baldwin whom we see and hear one last time will ever smile:

I'm not a nigger, I'm a man. But if you think I'm a nigger, it means you need him. The question that you've got to ask yourself, the white population of this country has got to ask itself. (...) If I'm not the nigger here and you invented him, you the white people invented him, then you've got to find out why (Baldwin in Peck 109).

But why did white people feel the need to invent Blacks? And why did white people invent serial girls as a way to invent blackness?

White women, and white serial girls especially, are one of the faces of whiteness in I Am Not Your Negro. They are as important as the shots of racist demonstrators and skin-heads, or as the groups of policemen seen hitting Black citizens. Both in Peck's film and in real life, white serial girls are at the same level as these men and their hatred, serving the same purpose. Thus, if misogyny creates the image of serial girls, then the objectification of women is a step towards their assassination. Serial girls implicitly serve another form of hatred, namely racism. In fact, serial girls are born at the intersection of misogyny and racism.

Another episode I am concerned with took place at Québec's national celebration, during the Saint-Jean Baptiste parade in downtown Montreal on the $24^{\text {th }}$ of June 2017. A man, standing on the sidewalk as the parade went by, filmed the first float and put the video up online. The video went viral and here follows my explanation.

The float was blue, the - needless to say, white - singer Annie Villeneuve stood on the float singing the classic Gens du pays. Around her, at the street level, was a group of white women dressed in white, singing and dancing as they followed the float, pushed by a group of young black men dressed in sable coloured clothes which recalled those worn by slaves. The organizers of the parade explained that this float was meant to represent 
Québec's flag: the singer represented the lys placed in the middle, surrounded by the blue coloured structure, while the women dressed in white represented the white borders of the flag. They also mention that the young men are part of a sports team from Montréal-Nord, a largely black neighbourhood. The students and their coach from a high school in the aforementioned neighbourhood were happy to participate in the parade. A donation was also made to the school by the major sponsor of the parade, the Société Saint-Jean Baptiste, which is a "sovereignist" NGO and "protector" of the French language.

Understandably, the float created a huge controversy in Montreal. But what caught my attention was precisely the cohabitation between the young black men pushing the float like anonymous slaves and the white women all dressed in white, almost indistinguishable one from the other, dancing carefree on the street just beside these kids. This was an image akin to what I found in Raoul Peck's movie, envisioning the combination of black and white enacted here in the image of black men beside the group of white women. This is the perfect image of a racism that does not dare to see itself as such. It is a racism that serves the fantasy of purity decreed by James Baldwin. Moreover, it privileges the purity of white women in opposition to impure Black women. Given the white fear of amalgamation between the races and the history of white male sexual lust for black females, bell hooks states that

we cannot rule out the possibility that white women were reluctant to acknowledge black women socially for fear of sexual competition. In general, white women did not wish to associate with black women because they did not want to be contaminated by morally impure creatures. White women saw black women as a direct threat to their social standing - for how could they be idealized as virtuous, goddess-like creatures if they associated with black women who were seen by the white public as licentious and immoral (hooks 130-1)?

It is not only a question of appearance, as Richard Dyer also suggests: "What is absent from white is anything; in other words, material reality. Cleanliness is the absence of dirt, spirituality the absence of flesh, virtue the absence of sin, chastity the absence of sex and so on" (Dyer 75). This fantastic absence of the body is constitutive of whiteness as 
invisible, non-existent, reflecting an unattainable ideal. This is what serial girls defend through the images that they perpetuated ever since the Tiller girls until today: showgirls with glowing white skin in sparkling, often white, costumes. Serial girls are women who are not real women. They are still-lives, fashion show mannequins prevented from eating, ethereal swans flying on white pointed shoes. They are ultimately fleshless, and hence unreal. It is this un-reality, this specific form of purity, the fantasy of a whiteness that brings with it a god-like quality which serial girls defend. We know these images by heart. And every time they appear, they make us feel good, just like a military formation has the power to both reassure and intimidate. They represent a power that deems to make them, and all those compared to them, powerless.

Serial girls suggest that whiteness is not only an expression of beauty, but also a supreme value. Serial girls are alike, and it is precisely their similarity what makes the image beautiful. At the same time, this similarity relies on and creates whiteness, regardless of whether the girls are actually white or not. It is the organisation of the bodies, the way they are aligned and dressed, their shape and the traits of their faces that create whiteness, the illusion of whiteness and whiteness as an illusion. It is the image itself that is white. The fact that the serial girls together are white, mesmerizing, angelic, otherworldly and frozen in time transforms them into the staging of whiteness as superior. This supremacy uses misogyny to make itself grand, and hence places white women in the position of accomplices.

The supremist white illusion is what needs to be undone. This is what feminists, especially intersectional and anti-racist feminists, have worked to undo throughout the years. One example is Anne Braden's "Letter to white southern women," published in December 1972, in the context of the demonstrations against the life sentencing of Thomas Wansley. He was a Black 26 year-old man, found guilty of rape even though he was accused by a white woman who was unable to identify him. Anne Braden denounced the myth of the Southern woman, which served anti-Black racism in the 7os just as it did during slavery. She unveiled the injustice hidden behind the statement of all white women against all Black men. A rape was considered a rape when the victim was a white woman and the criminal was a black man, but it did not exist with respect to Black women who were raped or to white men who were rapists. Also, it was not a crime when the woman was independent, when she was not or did not appear to be a man's wife, 
sister or daughter. In her letter, Anne Braden called out to white women, asking them to relinquish the privileges that came with the colour of their skin. These privileges are fake, she writes; they are a tool meant to separate you from your Black sisters in order to control them. Braden even quoted the monologue "A Black Woman Speaks of White Womanhood," written and performed by the actress Beulah Richardson:

It is right that I a woman

Black,

Should speak of white womanhood.

My fathers

My brothers

My husbands

My sons

Die for it, because of it. ...

White womanhood stands in bloodied skirt

And willing slavery

Reaching out adulterous hand

Killing mine and crushing me. ...

They said, the white supremacist said

That you were better than me,

That your fair brow should never know the sweat of slavery.

They lied.

White woman hood too is enslaved,

The difference is degree.

They brought me here in chains.

They brought you here willing slaves to man.

This complicity of white women with white supremacy has been denounced by a number of critics since the civil rights movement, including, of course, bell hooks, who parallels slavery with things as they are today:

It takes little imagination to comprehend the significance of one oppressed black woman being brutally tortured while the more privileged white women look passively at her plight. Incidents of this nature exposed to white women the cruelty of their husbands, 
fathers, and brothers and served as a warning of what might be their fate should they not maintain a passive stance. Surely, it must have occurred to white women that were enslaved black women not available to bear the brunt of such intense anti-women male aggression, they themselves might have been the victims (hooks 38).

As Barbara Smith writes in the seminal All the Women Are White, All the Blacks Are Men, But Some of Us Are Brave: "White women have a materially different relationship to the system of racism than white men. They get less out of it and often function as its pawns, whether they recognize this or not. It is something that living under white-male rule has imposed on us" (Smith et. al. 51). Audre Lorde supports the same aforementioned idea: "Mainstream communication does not want women, particularly white women, responding to racism. It wants racism to be accepted as an immutable given in the fabric of your existence, like evening time or the common cold" (Lorde 128). Thus, feminism's purpose is to undo this link between misogyny and racism. It is the job of white feminists to "step up to the plate" as bell hooks suggests and to be willing to look at themselves and admit their own - often unconscious or blind - complicity in a system that, albeit unjust, is less unjust to them (hooks and Yancy).

My analysis of serial girls also takes into consideration a discussion of the Barbie doll image. While Mattel has worked towards a diversity of bodies and skin colours in the Fashionista collection in the last few years, this movement towards inclusion has long been overdue. It is only a very small step towards the demise of the original Malibu Barbie which continues to be the main reference in terms of dolls. When one thinks of Barbie, they think of her as very blonde, very blue-eyed, too thin for her own good, with breasts too large and a waist and neck too small for a girl her size.

In 1940s, a test called "the doll test" was run by Mamie and Kenneth Clark. The test results led to the Court case Brown vs. Board of Education and to the desegregation of schools in the United States. The test showed that both white and non-white children to whom two dolls were presented - one white and one dark skinned - mostly considered the white doll to be pretty and nice, and the black doll to be ugly and bad. The same test was done again in 2010 and thereafter, according to a documentary made 
by $\mathrm{CNN}$ and Anderson Cooper4, it revealed not only similar results, but also a white bias which is more prevalent in white kids than in black or Latino children. The psychologists involved in the experiment suggested this bias to be less active in the black and Latino children because they were brought up by parents who strove to prepare their kids for a world in which they might very well not be welcomed easily.

I want to consider the prevalent image of white serial girls as a perpetual doll test that we are given through a myriad of images on a daily basis, regardless of whether we are conscious of it or not. However, it is a test with an implied answer. Serial girls are and must be white, beautiful, and nice, while Black women are ugly and bad. The Black women experience this perspective especially when they are not forced to be a part of the white series. For instance, fashion shows, in which $77.6 \%$ of the models are white, and advertisements like those of Victoria Secret support this demeaning view of Black women. Other proofs are the portrayals of Misty Copeland, principal dancer for the American Ballet Theatre and the first African American principal dancer in American history, or Serena Williams. Both tend to be described with words that link them either to animality or masculinity, as if femininity, in connection with these two activities mainly undertaken by white people - in the case of ballet, by white women particularly could not allow for black femininity.

Black women have and still are too often and automatically excluded from representations of beauty. Black forms of beauty are denigrated in favour of institutionalized white forms of beauty. Hence, the black body continues to be perceived as inferior and in need of constant alteration (Kinloch). Even today, Black women are often devalued, debased, animalized and masculinized while also being hypersexualized. In any case, they are seen as something that needs to be contained. From this perspective, the playwright Lorraine Hansberry, a Black militant and close friend of James Baldwin considers that:

I can be coming from eight hours on an assembly line or fourteen hours in Mrs. Halsey's kitchen. I can be all filled up that day with three hundred years of rage so that my eyes are flashing and my flesh is trembling - and the white boys in the streets, they look at me and think of sex. They look at me and that's all they think... Baby, you could be Jesus in

\footnotetext{
4 http://www.cnn.com/2010/US/05/13/doll.study/index.html.
} 
drag-but if you're brown they're sure you're selling (Hansberry, To Be Young, Gifted and Black 82)!

As Patricia Hill Collins explains, if white women have been encouraged to possess the four cardinal virtues - piety, purity, submissiveness and domesticity, Black women continue to be relegated to the position of the dangerous oversexed woman, a woman always too black, too African looking, hence not beautiful, wild, out of control, "sexually permissive, available and eager for the sexual assaults of any man, black or white. (...) The black female body gains attention only when it is synonymous with accessibility, availability, when it is sexually deviant" (in hooks 52). To this day, Black women are often perceived not only as inferior to their white blond haired blue-eyed counterparts, but as beings that need to be tamed and contained. As Valerie Felita Kinloch underlines in her reading of Vanessa William's win of the Miss America Pageant in 1984:

Many may not perceive the crowning of Williams as a sign of continued racism, although one could interpret the inclusion of black contestants as finalists as an indicator of a system of power that makes every attempt to contain race on its own terms of tolerance. This containment of blackness exists and is governed by a set of safe principles that reflect a discourse of whiteness that works to authenticate the identity, respectability, sexuality, morality, grace and femininity of white women.

This is also why hair is an important terrain of expression and opposition. The taming of Black female bodies is symbolized by the forced braiding of hair, by the deeming of black hair in its natural state as unkempt. Chimamanda Ngozi Adichie states in Americanah: "Relaxing your hair is like being in prison. You're caged in. Your hair rules you" (45). Brittney Cooper supports the same argument when writing about the American military ban on cornrows and locks:

But the specificity of these guidelines encodes a belief that something fundamental to black women's personhood and physical presence is excessive, unruly and must be subject to military discipline. (...) Black hair is political. And when black women choose for cultural, stylistic and/or health reasons not to conform to normative Euro-American 
beauty standards, our social structure - while sensitive to very little - is calibrated to detect and discipline away even the most diminutive forms of defiance.

White serial girls are a show of femininity. They are often represented wearing revealing clothing, yet they are not a show of sexuality. They remain similar to the German Hiller girls, who performed under the Third Reich. These tableaux vivants, akin to the military formations, were both a display of power and domestication, and a spectacle of the containment of the female body and sexuality. The Hiller girls were a type of antidote to women's (erotic) freedom. They were both the example and the counter-example, the illusion of freedom and the result of control. In the end, these women were pure ornaments, a flattened image, perfectly framed, mechanical, emptied of physicality and eroticism. They were perfectly contained.

This is where all formations of white serial girls say something important. We suggest that they all refer to each other and to the history of this serial structure, no matter if they are the DIM girls described by Giorgio Agamben in The Coming Community or staged by artist Vanessa Beecroft, or the dancers showcased at Le moulin rouge, Radio City music hall or in Taylor Swift's recent music video. As Rita Freedman writes in Beauty Bound about the Miss America Pageant - and this is most obvious during the swimsuit competition: "Miss America must be provocative but wholesome, a pretty but pure vestal virgin, like Cinderella." Here we have to hear what white serial girls say about how Black women are seen and represented. This is why it is important to reflect on what Black serial girls say about women, whiteness, racism and feminism. In fact, they go against the internalization of racism and against the ensuing self-hatred, contradictions and rage portrayed as white seriality. In this respect, Audre Lorde describes how

One black woman sits and silently judges another, how she looks, how she acts, how she impresses others. The first woman's scales are weighted against herself. ... She wishes the other woman would become someone else, anyone other another Black woman. She has enough trouble dealing with being herself. ... "Why don't you learn to fly straight," she says to the other woman. "Don't you understand what your poor showing says about us 
all? If I could fly I'd certainly do a better job than that. Can't you put on a more together show? The white girls do it. Maybe we could get one to show you how" (Lorde 167-8).

Serial white girls are a show of how to do it, of how to become a woman in a patriarchal heterosexist capitalist racist economy.

In the last part of this paper, I address the example of Beyoncé. The artist has expressed her feminism more and more forcefully since her 2013 Superbowl performance in which she "exploded all the symbols associated with the Super Bowl: football, male virility and violence" (Hobson). In fact, Beyoncé has become the face of pop feminism since her sampling of Chimamanda Ngozie Adichie's TED talk "We should all be feminists" in her song "Flawless". Moreover, she even sang and danced in front of the word "feminist" spelled in gigantic fluorescent letters on the stage of the VMA awards in 2014. Beyoncé is also the creator of Lemonade, a video album brought out to the public without any advance notice. Another video, "Formation," was released shortly before and it was part of the Lemonade event. As far as the script is concerned, it was written by poet Warsan Shire and addresses issues of betrayal, mourning and survival.

Beyoncé's feminism has been disqualified for a number of reasons, amongst which the most powerful is the accusation of being an antifeminist - or worse, a terrorist, as bell hooks has suggested (https://www.youtube.com/watch?v=rJkohNROvzs). Furthermore, the way she dresses and dances on stage, the sexualized nature of her performances and the female image that she carries and presents add more reasons to apparently dismiss her feminist perspective. But "If Beyoncé were white," as Aisha Shahidah Simmons (in Hobson) suggests,

she would definitely be called a feminist. But mainstream culture often doesn't recognize women of color in that way. As black women, we aren't even viewed as acting, as performing. Everything we do is supposed to be based in reality.

The critics of Beyoncé who question her feminism tend to foreground her body as a site of contestation, ignoring the historical victimisation and dehumanisation of black 
women on the grounds of their perceived hyper-sexuality (Weidhase). Feminists' and particularly white feminists' critique of Beyoncé ignore the history of Black womanhood, a history that has everything to do with white female seriality. This is what Beyoncé strives to undo with her army of women, embodying at once Black women's sexual agency beyond respectability, politics and the obligation of being contained. She fights racism and misogyny in the guise of one of their preferred tools: seriality. As Nathalie Weidhase writes: "Beyoncé's body does not contest her feminist status, instead her body contests the whiteness of mainstream feminism" (Weidhase 130).

Further on, I will discuss three moments in which Beyoncé tackled white female seriality, putting Black women "in formation" to resist racist misogyny.

The first one is her 2016 Superbowl half-time performance, when she brought with her on stage an army of women in Black Panther gear while she wore a bullet belt similar to Michael Jackson's. She faced off with Bruno Mars and his male gang, crashing Coldplay's act, with the song "Formation" that had just been released. "Now ladies let's get into formation," she sings, repeating the phrase "I slay" numerous times in this song which is a statement against racism and police brutality. In the "Formation" video, dropped the day before the Superbowl, a little boy is seen dancing in front of a line of police officers before the camera moves on to a graffiti that reads "Stop shooting us". This performance was widely criticized by a number of political figures including Rudy Giuliani, American politician and attorney to President Donald Trump. Moreover, after the Superbowl, Beyoncé launched her "Formation" tour, which provoked a reaction of resistance, as the Miami police union called for cops to boycott it.

The resistance to the tour originated in the negative reaction to the Black Panthers attire, afros and berets worn by the dancers, as a reference to both the antiracist movement from the 60s and 70s, and today's \#blacklivesmatter. It was not Beyoncé's first staging of a war between men and women, as "Run the world (girls)" is to be remembered too. But it was her first clear critical statement to use female seriality as definitively anti-racist and feminist. For example, a Saturday Night Live skit, entitled The Day Beyoncé Turned Black, was produced after the performance in order to mock people's reactions.

Moreover, in her SuperBowl half-time performance of 2013, seriality was already at stake, both on stage and in the video work that accompanied the piece. On the one 
hand, she surrounded herself with an all-woman 10-piece backing band, women back-up singers and 120 women dancers of diverse racial and ethnic backgrounds. On the other hand, the imagery projected on screen and on the floor was of a technologically serialized Beyoncé, a de-multiplication of two face to face female profiles that one could assume to be hers, drawn with lights on the stage. When Beyoncé appeared, she was just a human version of the other giant light projection behind her and her trademark silhouette. The image of this silhouette is a reference to and a repossession of both Charlie's Angels and the Playboy bunny. Thus, Beyoncé injects power where no power seems to exist. Throughout the performance, she is dressed in black leather, faces the camera, twerks, mimics seduction, but she always keeps a sense of irony. Her face and those of all the women with whom she dances and sings, as part of the group, are either stern or harsh most of the time. The performance ends with an autobiographic video where the audience can see scenes of Beyoncé's life, such as her childhood, her evolution as a singer, her relationship with Jay- $Z$, and her daughter. She seems to say that "this is what my life, my black life is. I am not a doll. I am not an image. I am a black woman." Thus, she forces us to read backwards and inject the reality of a woman's life in the imagery of seriality.

Beyoncé does the same in the second example I refer to, Lemonade. The author, Roxane Gay, speaks of "this new temporal reality that we are in: AL. After Lemonade." Although critical with respect to the artist, even bell hooks admits that Lemonade is the "construction of a powerfully black female sisterhood that resists invisibility, that refuses to be silent. ... it shifts the gaze of white mainstream culture. It challenges us all to look anew, to radically reenvision the black female body" (2016).

My analysis is interested in the way in which Beyoncé works against the containment of black female bodies using a form, seriality, army-like images as in the Superbowl formations or familial references in order to counter how black women are still perceived as too much. The dancers' natural hair, Beyoncé's chiffon yellow dress which barely contains her body, the baseball bat she uses to shatter car windows and surveillance cameras, the giant truck she drives over a car, the numerous scenes that show flowing tree branches, the hand-held camera shots, the mix between colonial and African inspired forms and materials in the women's costumes, Beyoncé fall off of the top of a building into a room filled with water in the opening scene, swimming with her 
hair flowing around her like the tentacles of a jellyfish until she opens the doors and lets the water out - these are all metaphors of black women's liberation. The freedom to move, to speak, to love and be loved are clearly opposed to the concept of containment. "The most disrespected person in America is the Black woman -" we hear Malcolm X say. Beyoncé herself borrows the words of Warsan Shire such as "I'm just too much for you," "women like her cannot be contained," "one thousand girls raise their arms."

There is a lot of whiteness in Lemonade, yet there are no white women. It is as if Beyoncé would say that whiteness does not belong to them, that white women have to become undone, and that Black women are not deprived of what white stands for in this world. "I was served lemons but I made lemonade," says Hattie, Beyoncé's mother-inlaw, filmed during her $90^{\text {th }}$ birthday party. Thus, we could assume that the lemons served take shape of white serial girls and of everything that accompanies them.

I will end my analysis with a fabulous moment which took place in November 2016, during the Country Music Awards, when Beyoncé interpreted her song "Daddy lessons," from Lemonade, with the Dixie Chicks. She performed it not long before the American elections, not long after she had performed for Hilary Clinton and not long before Donald Trump was elected.

There, during the CMAs, white serial girls were not exactly white anymore, and country music was forced to look at its own racist and misogynistic bias. It was not only a question of a pop queen Bey ending up on a country music stage, but of a black woman re-opening doors for white women who had been black listed by those who had once adored them. When Nathalie Maines, Dixie Chicks's lead singer, told a crowd in London, before the invasion of Iraq in 2003, that she stood with pacifists and was ashamed that President George W. Bush was from Texas, the group was disowned by the country music radio, their albums were burned, and their lives were threatened. Beyoncé was born in Texas. On that night, at the CMAs, she was the first one to speak, followed by Nathalie Maines, as if both of them planned to highjack the event. Beyoncé did not belong to the CMA because of her music, and nor did the Dixie Chicks because of their politics.

However, what is interesting for us today is how seriality was used and misused, in order to undo, to reveal racism and misogyny as unbecoming. Dressed in a very ornate long sheer white dress, Beyoncé performed her song "Daddy Lessons" with a cast of 
mainly black musicians dressed in white. On the other hand, the white blonde-haired country musicians, the Dixie Chicks, were clad in bandit black. Moreover, a few lines of their song “Long Time Gone” were inserted in Beyoncé's lines. If Beyoncé's song is about a father teaching his daughter to shoot if put in danger by a man, the Dixie Chicks' song about a dying town was a momentous song to sing on the eve of the 2016 elections.

Thus, the journalist Wesley Morris who wrote about the CMA show was right to assume that Beyoncé is now a "star we have to need. She can't stop signifying. Suddenly, she's being asked to do for persecuted white women what Oprah Winfrey does for books." The Dixie Chicks end up speaking Beyoncé and the result is a replay of white serial girls upside down, inside out, undone:

Packing part of a song about a decaying heartland into a number about a woman's right to fend off an injurious man and playing that song at a country-music awards show less than a week before a presidential election and doing so as an interracial band of outlaw feminist superstars whose patriotism has been, at various times, deemed suspect and whose performance together gets a big ovation anyway must be considered some kind of triumph (Morris).

However, as Nathalie Maines tweeted on the day after the performance, in reaction to racist comments and a country music backlash against all women who performed on the CMA stage that night: "If we all turn this up really loud, together we can drown out the hate."

\section{References}

Adichie, Chimamanda Ngozie. Americanah. Toronto: Vintage Canada, 2014.

Agamben, Giorgio. The Coming Community. Minneapolis: University of Minnesota Press, 1993.

Baldwin, James. The Devil Finds Work. The Dial Press, 1976.

Beyoncé. Lemonade. Parkwood Entertainment and Columbia Records, 2016.

Bouteldja, Houria. Les Blancs, les Juifs et nous. Paris : La Fabrique, 2016.

Braden, Anne. A Letter to White Southern Women. Louisville: SCEF, 1972. 
METACRITIC JOURNAL FOR COMPARATIVE STUDIES AND THEORY 4.1

Cooper, Brittney. "The Politics of Back Women's Hair: Why It's Seen With Skepticism”, https://www.salon.com/2014/04/22/the politics of my black hair why its seen with skepticism and a need to discipline/.

Dyer, Richard. White. New York: Routledge, 1997.

Freedman, Rita. Beauty Bound. New York: Prentice Hall and IBD, 1985.

Hansberry, Lorraine. To Be Young, Gifted and Black. New York: Signet, 2011.

---. "Moving Beyond Pain", May 9, 2016,

http://www.bellhooksinstitute.com/blog/2016/5/9/moving-beyond-pain.

Hobson, Janelle. "Beyonce's Fierce Feminism ”,

http://msmagazine.com/blog/2015/03/o7/beyonces-fierce-feminism.

hooks, bell. Ain't I A Woman?, London/New York: Routledge, 1981 (2015).

Kinloch, Valerie Felita. "The Rhetoric of Black Bodies" in "There She Is, Miss America." The Politics of Sex, Beauty and Race in America's Most Famous Pageant. New York: Plagrave Macmillan, 2004.

Lorde, Audre. Sister Outsider. Berkeley: Crossing Press, 1984 (2007).

Morris, Wesley. “Beyoncé's True Political Statement This Week? It Wasn't at a Clinton Rally", https://www.nytimes.com/2016/11/06/arts/music/beyonce-politicalhillary-clinton-dixie-chicks.html.

Morrison, Tony. "Mourning for Whiteness" in The New Yorker, Nov 21 2016, https://www.newyorker.com/magazine/2016/11/21/aftermath -sixteenwriters-on-trumps-america.

Peck, Raoul, James Baldwin. I Am Not Your Negro. A Major Motion Picture Directed by Raoul Peck From Texts by James Baldwin. Vintage Books, 2017.

Richardson, Beulah. "A Black Woman Speaks of White Womanhood”. New York: American Women for Peace, 1951.

Roediger, David R. (ed.). Black On White. Black Writers On What It Means To Be White. New York: Shocken Books, 1998.

Smith, Barbara, Akasha (Gloria T.) Hull, Patricia Bell-Scott. But Some of Us Are Brave. New York: The Feminist Press, 1982 (2015).

Weidhase, Nathalie. "'Beyoncé Feminism' and the Contestation of the Black Feminist Body” in Celebrity Studies. London: Routledge, 6:1, 128-131, 2015. 
Yancy, George, and bell hooks. "bell hooks: Budhism, the Beats and Loving Blackness", in The New York Times, Dec 10 2015, https://opinionator.blogs.nytimes.com/2015/12/10/bell-hooks-buddhism-thebeats-and-loving-blackness/.

---. "Dear White America" in The New York Times, Dec 24 2015, https://opinionator.blogs.nytimes.com/2015/12/24/dear-white-america/. 